\title{
Effects of marine reserve protection on the mud crab Scylla serrata in a sex-biased fishery in subtropical Australia
}

\author{
S. Pillans ${ }^{1,3,6, *}$, R. D. Pillans ${ }^{2}$, R. W. Johnstone ${ }^{1,3}$, P. G. Kraft ${ }^{4}$, M. D. E. Haywood ${ }^{2}$, \\ H. P. Possingham ${ }^{5}$ \\ ${ }^{1}$ CRC for Coastal Zone, Estuary and Waterway Management, Indooroopilly Sciences Centre, 80 Meiers Road, \\ Brisbane 4068, Queensland, Australia \\ ${ }^{2}$ CSIRO Marine Research, PO Box 120, Cleveland, Brisbane 4163, Queensland, Australia \\ ${ }^{3}$ Centre for Marine Studies, ${ }^{4}$ Department of Zoology and Entomology, and ${ }^{5}$ The Ecology Centre, University of Queensland, \\ St. Lucia, Brisbane 4072, Queensland, Australia \\ ${ }^{6}$ Present address: Centre for Marine Studies, University of Queensland, St. Lucia, Brisbane 4072, Queensland, Australia
}

\begin{abstract}
The impact of sex-biased fishing and marine reserve protection on the mud crab Scylla serrata was examined by comparing the catch rates (catch-per-unit-effort, CPUE), mean size, sex ratios and movement of crabs in 2 coastal marine reserves ( 1.9 and $5.7 \mathrm{~km}^{2}$ ) and 4 fished non-reserve sites in subtropical Australia. Five years after closure, both marine reserves supported higher catch rates and a larger mean size of $S$. serrata than non-reserve sites. Males dominated catches of $S$. serrata in both marine reserves, where CPUE was at least twice as high within the reserves compared to non-reserve sites. Male crabs were also $10 \%$ larger in the reserves compared to adjacent fished areas, and of the total male catch, over $70 \%$ were equal to or greater than legal size compared to less than $50 \%$ outside the reserves. The sex ratio of $S$. serrata was skewed towards females in all nonreserve sites, which was most likely a result of the ban on taking female $S$. serrata in Moreton Bay. As only male crabs of $\geq 15 \mathrm{~cm} C W$ made up the $S$. serrata fishery in Moreton Bay, sex ratios of mature male and female crabs were examined, revealing a strong skew (2:1) towards mature males in both marine reserves. Of the $472 \mathrm{~S}$. serrata captured in this study, 338 were tagged in the reserves in order to document movement of the crabs between the reserve and non-reserve sites. Of the 37 recaptured crabs, $73 \%$ were recorded inside the reserves, with some spillover (i.e. cross-boundary movement) of crabs recorded in fished areas. This study demonstrates the effectiveness of small $\left(<6 \mathrm{~km}^{2}\right)$ marine reserves for sex-biased exploited fisheries species.
\end{abstract}

KEY WORDS: Marine reserves $\cdot$ Scylla serrata $\cdot$ Sex-biased fishery $\cdot$ CPUE $\cdot$ Sex ratio $\cdot$ Reserve size $\cdot$ Subtropical · Australia

Resale or republication not permitted without written consent of the publisher

\section{INTRODUCTION}

Due to the ongoing direct depletion of the world's marine resources as well as the indirect effects of fishing, no-take marine reserves are being promoted as an ecosystem-level management tool. No-take marine reserves (referred to as 'marine reserves' in this paper) prohibit extractive activities such as fishing, offering a way to conserve marine biodiversity whilst at the same time sustaining fisheries (Roberts \& Hawkins 2000, Ward et al. 2001, Halpern 2003, Lubchenco et al. 2003). Marine reserves provide an additional fisheries management tool that has the potential to dramatically reverse the detrimental effects of fishing (Dugan \& Davis 1993, Roberts \& Hawkins 2000). There is unequivocal evidence that fishing reduces the abun- 
dance and size of the most reproductively valuable members of a population (Chapman \& Kramer 1999, Edgar \& Barrett 1999, Johnson et al. 1999, McClanahan et al. 1999, Chiappone et al. 2000, Willis et al. 2003, Williamson et al. 2004). Recent empirical evidence suggests that establishing well-designed and managed marine reserves can result in rapid increases in the size and abundance of once exploited species (see empirical studies within the following reviews: Gell \& Roberts 2003, Halpern 2003, Lubchenco et al. 2003).

The species most likely to show dramatic responses to reserve protection will have limited movements, and age and size distributions that have been lowered by fishing pressure (Rowley 1994). The mud crab Scylla serrata (Forksal) is a large aggressive portunid crab largely fished throughout the Indo-Pacific region, and within Australia it occurs in tropical and warm water mangrove-lined estuaries from southern New South Wales north to Exmouth Gulf in Western Australia (Heasman 1980, Kailola et al. 1993, Williams 2002). Juvenile crabs inhabit intertidal regions associated with mangroves (Fielder \& Heasman 1978) whilst adult crabs spend most of their lives restricted to sheltered inshore and estuarine areas, associated with deeper subtidal regions (Hill 1975, 1978, Hill et al. 1982, Hyland et al. 1984). S. serrata live in burrows which provide protection to crabs during their moulting and mating periods, when they are most vulnerable (Fielder \& Heasman 1978). S. serrata is a fast-growing species which can, depending on water temperature, recruit to the fishery and reach sexual maturity within 18 to 36 mo (Fielder \& Heasman 1978, Heasman 1980). As $S$. serrata reach maturity, noticeable differences between the sexes become obvious. Male $S$. serrata are larger than females (at maturity) and large male claws (17 cm CW) make up $45 \%$ of total male weight whereas claws contribute only $22 \%$ of the weight for equivalent-width females (Hill 1976). The major threats to $S$. serrata populations in Moreton Bay are damage to burrows, loss of mangrove habitat and increasing fishing pressure (Williams 2002).

In the subtropical and tropical waters of Australia, Scylla serrata is a highly sought-after crustacean (Kailola et al. 1993, Williams 2002). In Queensland, a unique fishery exists for $S$. serrata where 2 types of catch restrictions apply, a sex limit and a size limit. The legal-size for male $S$. serrata is $15 \mathrm{~cm} \mathrm{CW}$ and no female crabs can be taken in Moreton Bay. These regulations were designed to ensure the maintenance of the spawning stock by allowing crabs to reproduce before being exposed to the fishery (Brown 1993, Coates 1993). The commercial fishing effort for S. serrata in Moreton Bay has been categorized as high (Zeller 1998), producing approximately $11 \%$ of the
State's harvest which in 2003 was worth an estimated $\$ 1.2$ million (Williams 2002, CHRIS 2003). In 2003, the commercial harvest for $S$. serrata in Moreton Bay recorded its highest annual catch in 15 yr (113.3 t), which is the result of an increased effort from both the number of boats used and the number of days fished (Williams 2002, CHRIS 2003). Interestingly, since 1997 the recreational harvest (approximately 260 t) has exceeded the commercial harvest in Moreton Bay (Williams 2002).

Simple identification of male and female Scylla serrata in the field, which in most fish species is almost impossible, enabled us to determine sex ratios in this study. The only records documenting sex ratios of $S$. serrata in the Moreton Bay fishery are population estimates carried out by fisheries agencies more than $10 \mathrm{yr}$ ago. These revealed that, although there were seasonal variations in sex ratios, adult female mud crabs often outnumbered adult male crabs (Coates 1993); no doubt a result of the male-only fishery. Several studies have assessed the effects of fishing on sex ratios of protogynous hermaphroditic fish (Roberts \& Polunin 1991, Buxton 1992, 1993, Hawkins \& Roberts 2003), and have reported greater frequencies of exploited males within reserves for male-only fisheries. We are not aware of any studies that assess the impacts of a sex-biased (invertebrate) fishery together with the effects of marine reserve protection; however, a number of studies looking at sex ratios of the partially protected (i.e. protection of ovigerous females) spiny lobster Jasus edwardsii in New Zealand have revealed differences in sex ratios of $J$. edwardsii between marine reserves and adjacent fished sites (MacDiarmid \& Breen 1992, Davidson et al. 2002, Kelly et al. 2002). Due to the intense fishing pressure, limited movement and relatively well-established populations within Moreton Bay, S. serrata was chosen as the species most likely to show dramatic responses to reserve protection.

The aim of this study was to assess the effects of sexbiased fishing on Scylla serrata populations in 2 established marine reserves in subtropical Australia. More specifically, we assessed the effects of marine reserve protection on mud crabs by comparing the catch rates, mean size, size distribution, sex ratio and movement of $S$. serrata between 2 marine reserves and 4 nonreserve sites. We tested the predictions that marine reserve protection would increase the catch rates, mean size and size distribution of $S$. serrata in the reserves compared to the non-reserve sites. We also predicted increases in the catch rates and mean size of male crabs in the reserves compared to areas exposed to sex-biased fishery and that sex ratios of mature $S$. serrata would be skewed towards females in nonreserve sites. In addition, we predicted that the major- 
ity of $S$. serrata would remain within the reserves with some spillover (i.e. cross-boundary movement) into fished non-reserve sites expected.

\section{MATERIALS AND METHODS}

Study sites. This study was conducted in the Moreton Bay Marine Park $\left(27^{\circ} 25^{\prime} \mathrm{S}, 153^{\circ} 20^{\prime} \mathrm{E}\right)$, which is a semi-enclosed subtropical bay covering an area of approximately $3400 \mathrm{~km}^{2}$ (Environmental Protection Agency 1999). The 2 reserve sites surveyed were Tripcony Bight reserve $\left(5.7 \mathrm{~km}^{2}\right.$ in area) in the northern tip of the Marine Park and Willes Island reserve $\left(1.9 \mathrm{~km}^{2}\right.$ in area) located in southern Moreton Bay (Fig. 1). Tripcony Bight and Willes Island reserves are dominated by mud flats and seagrass beds (Zostera capricorni, Halophila ovalis and algae Caulerpa taxifolia), and are fringed by mangrove species (Lumnitzera racemosa and Bruguiera gymnorhiza, respectively). Both marine reserves were established in 1997 and are complete no-take areas managed under 1 government department (QPWS Queensland Parks and Wildlife Service) in accordance with the Marine Parks Act 1982 (Queensland Parliamentary Counsel 1997).

Survey design. No baseline data was available before the implementation of the reserves, so a beforeafter-control-impact (BACI) experimental design could not be used (Underwood 1994). The 2 marine reserves surveyed in this study were located at opposite ends of Moreton Bay; Tripcony Bight reserve in the north and Willes Island reserve in the south. For each reserve site, 2 nearby and comparable non-reserve (fished) sites were chosen and surveyed to increase comparisons within sites for differences associated with spatio-temporal variability (Garcia-Charton et al. 2000). Non-reserve sites were chosen on the basis of proximity to reserve sites (no more than $7 \mathrm{~km}$ north or south of reserves; referred to as boundary non-reserves [NRB] and far non-reserves [NR]), habitat similarities (such as habitat and substrate type and vegetation coverage) and hydrodynamic conditions (such as flow rates, depth and water chemistry).

As surveys of Scylla serrata were replicated at the reserve level, any intrinsic differences in habitat and/or location could be reduced by averaging the 2 reserves ( $\mathrm{R}=$ Reserves; Tripcony Bight [TB] and Willes Island [WI] reserves). Non-reserve sites were also averaged depending on their geographical location and proximity to the reserve (i.e. boundary nonreserves $\mathrm{NRB}_{\mathrm{TB}}+\mathrm{NRB}_{\mathrm{WI}}$ and far non-reserves $\mathrm{NR}_{\mathrm{TB}}+$ $\mathrm{NR}_{\mathrm{WI}}$ ). Each non-reserve site was open to fishing and experienced different levels of fishing pressure. For example, in the non-reserve sites associated with the Tripcony Bight reserve, only recreational fishing is permitted whereas in the non-reserve sites associated with the Willes Island reserve both commercial and recreational fishing is allowed. Sampling was carried out at all study sites during summer (JanuaryFebruary) and winter (July-August) each year over a 2 yr period from February 2002 to August 2003.

Crab surveys. Sampling within fully protected reserves needs to be non-destructive and at the same time maximize the amount of data collected (Edgar \& Barrett 1997). The most non-obtrusive and practical method of sampling Scylla serrata is to use catch and release sampling using baited crab pots (Williams \& Hill 1982). The crab pots used in this study were

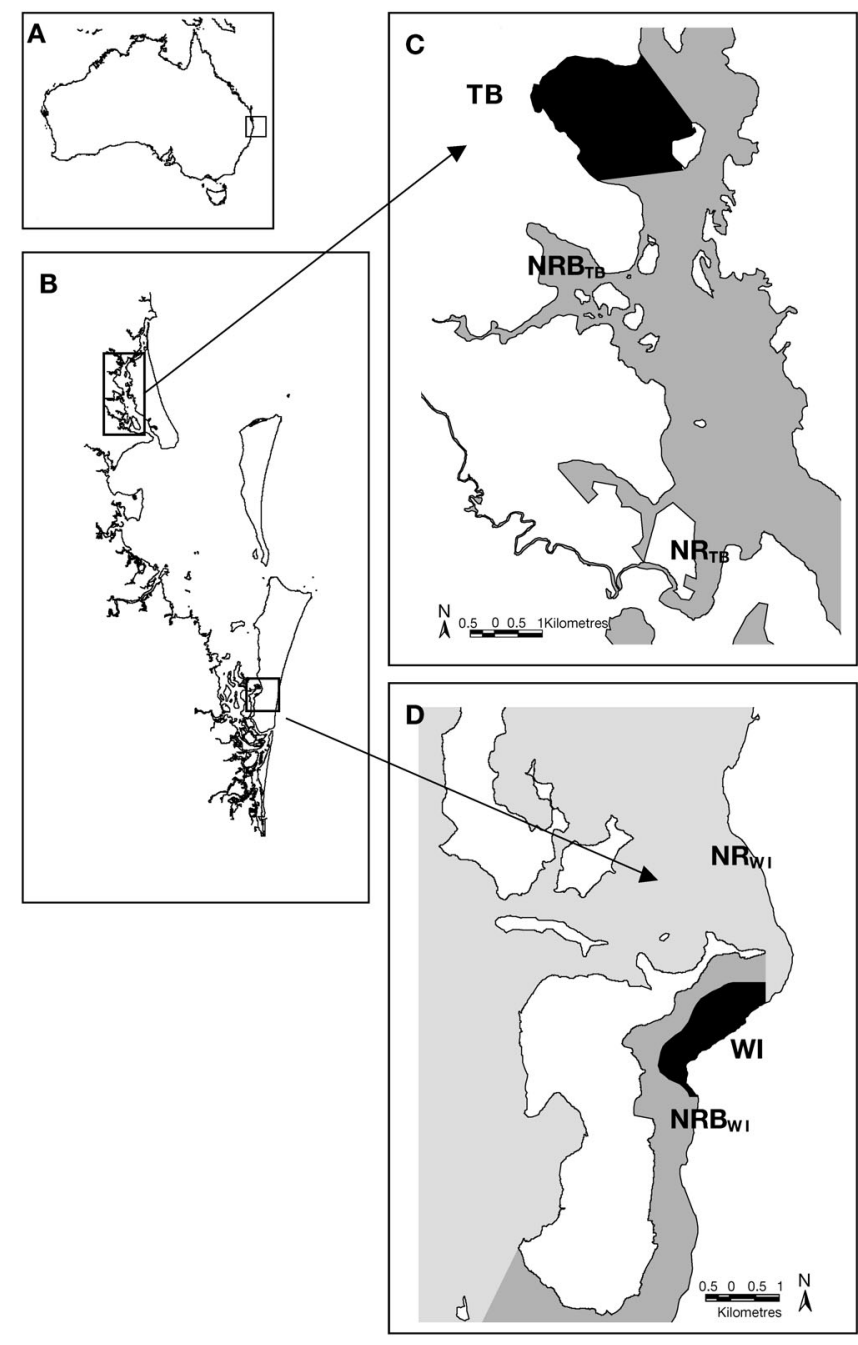

Fig. 1. (A) Map of Australia. Insert shows location of the study area in subtropics. (B) Map of the Moreton Bay Marine Park. Inserts show the 2 marine reserves surveyed in this study. (C) Map of Tripcony Bight reserve (TB) and associated non-reserve sites ( $\mathrm{NRB}_{\mathrm{TB}}$ : boundary non-reserve; $\mathrm{NR}_{\mathrm{TB}}$ : far non-reserve). (D) Map of Willes Island reserve (WI) and associated non-reserve sites $\left(\mathrm{NRB}_{\mathrm{WI}}\right.$ : Boundary non-reserve; $\mathrm{NR}_{\mathrm{WI}}$ : far non-reserve) 
designed to catch large sub-adult/adult feeding crabs (Heasman 1980, Hill et al. 1982, Williams \& Hill 1982), which is the same harvest method used by both commercial and recreational fishers in Moreton Bay (Williams 2002). Each day, 11 crab pots were baited with mullet Mugil cephalus and set randomly, but at least $50 \mathrm{~m}$ apart (Williams \& Hill 1982), within the study sites at depths ranging between 1 and $4 \mathrm{~m}$. The pots were checked $24 \mathrm{~h}$ after setting and all crabs captured were identified to species, measured, sexed and released. Relative abundance of crabs, expressed as CPUE in this study, was defined as the number of crabs caught per pot. Carapace width $(\mathrm{CW}, \mathrm{cm})$ of each crab was measured between the tips of the ninth antero-lateral spines. Pots were then re-baited and reset at random to maximize coverage of sites and to allow pots to 'fish' for $48 \mathrm{~h}$ at each study site. This method was repeated at each study site during summer and winter for a $2 \mathrm{yr}$ period (i.e. 44 pot lifts per site per year).

Due to the selective nature of the mud crab fishery in Moreton Bay, we were also able to assess the impacts of sex-biased fishing by determining the sex ratios of crabs between reserve and non-reserve sites. As only male crabs of $\geq 15 \mathrm{~cm}$ CW made up the Scylla serrata fishery in Moreton Bay, only mature male and female crabs were used in the comparison of sex ratios. The maturity of $S$. serrata can be deduced from minimum size limits (MSL). The MSL in a fishery is generally dependent on the size at which the target species matures (Robertson \& Kruger 1994). In Moreton Bay, male $S$. serrata moult to adult body form (i.e. maturity) between 14 and $16 \mathrm{~cm} \mathrm{CW} \mathrm{(Heasman} \mathrm{1980).}$ Mating pairs of $S$. serrata in Moreton Bay predominantly comprise females passing through their terminal moult at a mean premoult carapace width of $12.8 \pm 0.8 \mathrm{~cm}$, and larger intermoult terminal instar males of mean carapace width $16.5 \pm 1.0 \mathrm{~cm}$ (Heasman et al. 1985). The mature sizes used in the comparison of sex ratios in this study were, therefore, of mature males (legal-sized, $\geq 15 \mathrm{~cm} \mathrm{CW}$ ) and mature females $(\geq 12 \mathrm{~cm} \mathrm{CW})$.

Crab movement. Commencing in summer 2003 and continuing through to summer 2004, all Scylla serrata $>10 \mathrm{~cm} \mathrm{CW}$ caught were also tagged. To document the movement of crabs, plastic T-bar anchor tags (Hallprint) were used to mark the crabs, as described by Hill (1975). The tags were imprinted with a freecall phone number. Hill (1975) found that tagging $S$. serrata did not alter the behavior of crabs and that tags were retained after moulting. The distance moved refers to the distance between the release and the recapture site of crabs (Hyland et al. 1984). In this study, spillover is defined as crossboundary movement of crabs with no implication for density-dependence as defined by Kramer \& Chapman (1999).

Data analysis. Catch rates: Catch rates (CPUE) of Scylla serrata were tested for normality (KolmogorovSmirnov test, Zar 1984) but as the data were counts and contained many zeros, they did not satisfy the assumptions of normality or homogeneity of variance. The data were, therefore, analyzed with a generalized linear model (GLM) under the assumption of a Poisson distribution. The model was fitted using maximum likelihood methods by the SAS procedure GENMOD (SAS 2003). The factors used in the analysis were 'location' (north, south), 'status' (reserve, nonreserve), 'season' (summer, winter) and 'sex' (male, female), which were all treated as fixed factors. Ratios describing the magnitude of differences between the main effects were calculated after non-significant interactions were progressively removed from the model (see Willis et al. 2003 for a more comprehensive explanation of this methodology). Further analysis on the catch rates of male and female $S$. serrata between the 2 marine reserves and 4 non-reserve sites were also carried out (separately) using the same GLM.

Size: As the mean size (per pot) data of Scylla serrata had a non-normal distribution, differences between reserve and non-reserve sites were tested using nonparametric tests (Zar 1984). A Kruskal-Wallis 1-way ANOVA was used to test the mean size of crabs between the reserve and non-reserve sites (using factor status). The mean sizes of all crabs (males and females) were tested as were male and female $S$. serrata data sets. Length-frequency distributions (\%) of $S$. serrata from both reserves and non-reserve sites (total catch) were then compared using a chi-square goodness of fit test (Zar 1984). Separate tests were also performed on size distribution data for male and female crabs.

Sex ratio: As the factor sex interacted with all measures tested (i.e. CPUE and mean size), we looked at the sex ratio among and between study sites. Mature sizes used in the comparison of sex ratios in this study were of mature males (legal-sized, $\geq 15 \mathrm{~cm} \mathrm{CW}$ ) and mature females $(\geq 12 \mathrm{~cm} \mathrm{CW})$. Sex ratios were compared between reserve and non-reserve sites using a chi-square goodness of fit test for departure from 1:1 (Zar 1984).

Crab movement: The total number of Scylla serrata tagged within both marine reserves and non-reserve sites was recorded, and recaptures were expressed as a percentage for each site. The total time from release to recapture, and the distance moved from the capture site, were recorded for each recapture. The growth of crabs will not be discussed in this paper due to the short time frame of this tagging study. 
Table 1. Scylla serrata. Summary of relative abundance (n) and mean size (cm CW) with SE $( \pm 1)$ for total mud crabs and male and female crabs caught between study sites (seasons pooled). Total catch and male mud crabs also include the percentage of legalsized crabs $(\geq 15 \mathrm{~cm} \mathrm{CW})$ caught. TB: Tripcony Bight reserve; $\mathrm{NRB}_{\mathrm{TB}}$ : Tripcony Bright boundary non-reserve; $\mathrm{NR}_{\mathrm{TB}}$ : Tripcony Bright far non-reserve; WI: Willes Island reserve; $\mathrm{NRB}_{\mathrm{WI}}$ : Willes Island boundary non-reserve; $\mathrm{NR}_{\mathrm{WI}}$ : Willes Island far non-reserve

\begin{tabular}{|c|c|c|c|c|c|c|c|c|c|c|c|c|}
\hline \multirow[t]{2}{*}{ Location } & \multirow[t]{2}{*}{ Site } & \multicolumn{4}{|c|}{ - Total } & \multirow[b]{2}{*}{$\mathrm{n}$} & \multirow[b]{2}{*}{ Size } & \multicolumn{2}{|c|}{ Male } & \multirow{2}{*}{$\overline{\mathrm{n}}$} & \multicolumn{2}{|c|}{ Female } \\
\hline & & $\mathrm{n}$ & Size & $\mathrm{SE}( \pm 1)$ & $\%$ legal & & & $\mathrm{SE}( \pm 1)$ & $\%$ legal & & Size & $\mathrm{SE}( \pm 1)$ \\
\hline \multirow[t]{3}{*}{ North } & TB & 133 & 15.7 & 0.135 & 52 & 97 & 15.4 & 0.149 & 71 & 36 & 16.4 & 0.265 \\
\hline & $\mathrm{NRB}_{\mathrm{TB}}$ & 98 & 14.7 & 0.180 & 14 & 56 & 14.1 & 0.201 & 25 & 42 & 15.6 & 0.273 \\
\hline & $\mathrm{NR}_{\mathrm{TB}}$ & 30 & 15.8 & 0.335 & 20 & 14 & 14.7 & 0.387 & 43 & 16 & 16.8 & 0.405 \\
\hline \multirow[t]{3}{*}{ South } & WI & 130 & 16.1 & 0.139 & 59 & 94 & 16.2 & 0.173 & 82 & 36 & 15.8 & 0.213 \\
\hline & $\mathrm{NRB}_{\mathrm{WI}}$ & 43 & 15.5 & 0.263 & 9 & 18 & 14.2 & 0.305 & 22 & 25 & 16.5 & 0.251 \\
\hline & $\mathrm{NR}_{\mathrm{WI}}$ & 38 & 15.4 & 0.285 & 24 & 20 & 14.8 & 0.398 & 45 & 18 & 16.0 & 0.360 \\
\hline
\end{tabular}

\section{RESULTS}

\section{Catch rates and sex}

Over the 2 yr period of this study, a total of 472 mud crabs were recorded from the 2 marine reserves and non-reserve sites. A summary of total catch rates (n)

Table 2. Scylla serrata. Likelihood ratio statistics for CPUE (no. of crabs per pot) of total mud crabs, and male and female crabs caught at 2 marine reserves (Tripcony Bight and Willes Island) and 4 non-reserve sites surveyed 4 times over a 2 yr period. Location: north, south; Status: reserve, non-reserve; Season: summer, winter; Sex: male, female. Non-significant $(p>0.05)$ interaction terms have been removed from the model

\begin{tabular}{|lrrrrrrrr|}
\hline Source & df & \multicolumn{2}{c}{ Total } & \multicolumn{2}{c}{ Male } & \multicolumn{2}{c|}{ Female } \\
& & \multicolumn{1}{c}{$\chi^{2}$} & $\mathrm{p}$ & $\chi^{2}$ & $\mathrm{p}$ & $\chi^{2}$ & $\mathrm{p}$ \\
\hline Location & 1 & 5.3 & 0.02 & 4.1 & 0.04 & 1.3 & 0.2 \\
Status & 2 & 125.2 & 0.0001 & 131.2 & 0.0001 & 16.1 & 0.0003 \\
Season & 1 & 15.0 & 0.0001 & 4.1 & 0.04 & 14.0 & 0.0002 \\
Sex & 1 & 34.0 & 0.0001 & - & & - & \\
Location $\times$ Status & 2 & 17.7 & 0.0001 & 17.4 & 0.0002 & 3.1 & 0.2 \\
Location $\times$ Season & 1 & 4.5 & 0.03 & 3.2 & 0.07 & 1.3 & 0.2 \\
Status $\times$ Sex & 2 & 22.6 & 0.0001 & - & & - & \\
\end{tabular}

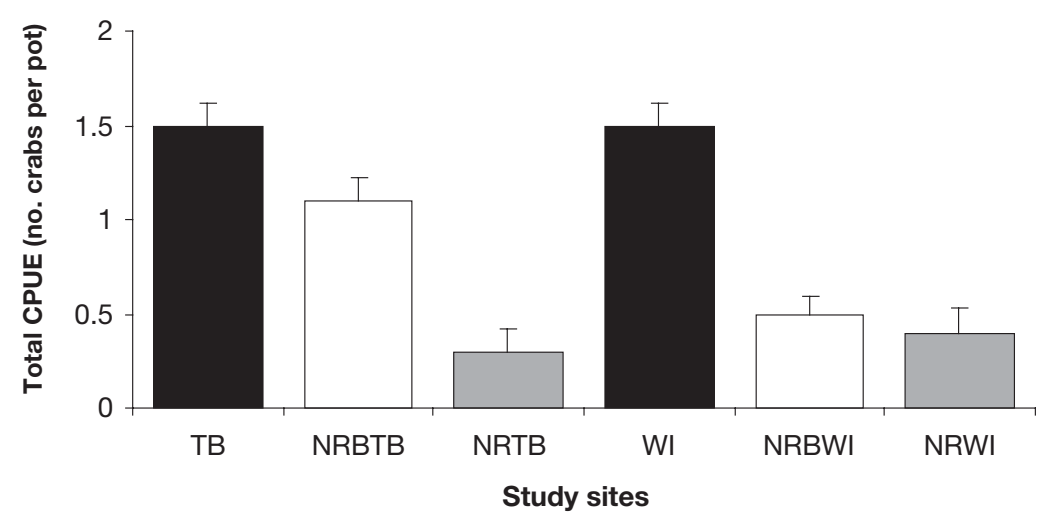

Fig. 2. Scylla serrata. Total catch rates (no. of crabs per pot) $( \pm 1 \mathrm{SE})$ of mud crabs (male and female crabs) between the 2 reserves (TB: Tripcony Bight; WI: Willes Island) and corresponding non-reserve sites (NRB: boundary non-reserve; NR: far non-reserve) (seasons pooled) and mean size of Scylla serrata between all study sites (seasons pooled), and between male and female mud crabs is displayed in Table 1.

The log-linear model fit to catch rates of total crabs (male and females) resulted in significant interactions between location and status, location and season, and status and sex (Table 2). At both locations, catch rates of Scylla serrata were 2-and-a-half times higher in the reserves compared to non-reserve sites (Fig. 2). The only exception were the catch rates of crabs in the Tripcony Bight boundary nonreserve site $\left(\mathrm{NRB}_{\mathrm{TB}}\right)$ which were only marginally lower than catch rates within the Tripcony Bight reserve and much higher than catch rates of crabs within the corresponding non-reserve sites (Table 1). A seasonal pattern in catch rates of $S$. serrata was evident in both reserves, with higher catch rates of crabs in summer compared to winter months. Catch rates of $S$. serrata also appeared to peak in summer 2003 in the northern sites $\left(\mathrm{TB}, \mathrm{NRB}_{\mathrm{TB}}\right)$ compared to the southern sites over the same season (see Fig. 4A). Catch rates of crabs within the non-reserve sites were more variable throughout the seasons.

The best statistical model for catch rates of male Scylla serrata resulted in a significant interaction between location and status, with no significant interactions with season (Table 2). Higher catch rates of male crabs were recorded in both marine reserves compared to the non-reserve sites (Fig. 3A). Catch rates between the non-reserve sites did not differ greatly, with the exception of catches in the Tripcony Bight boundary 

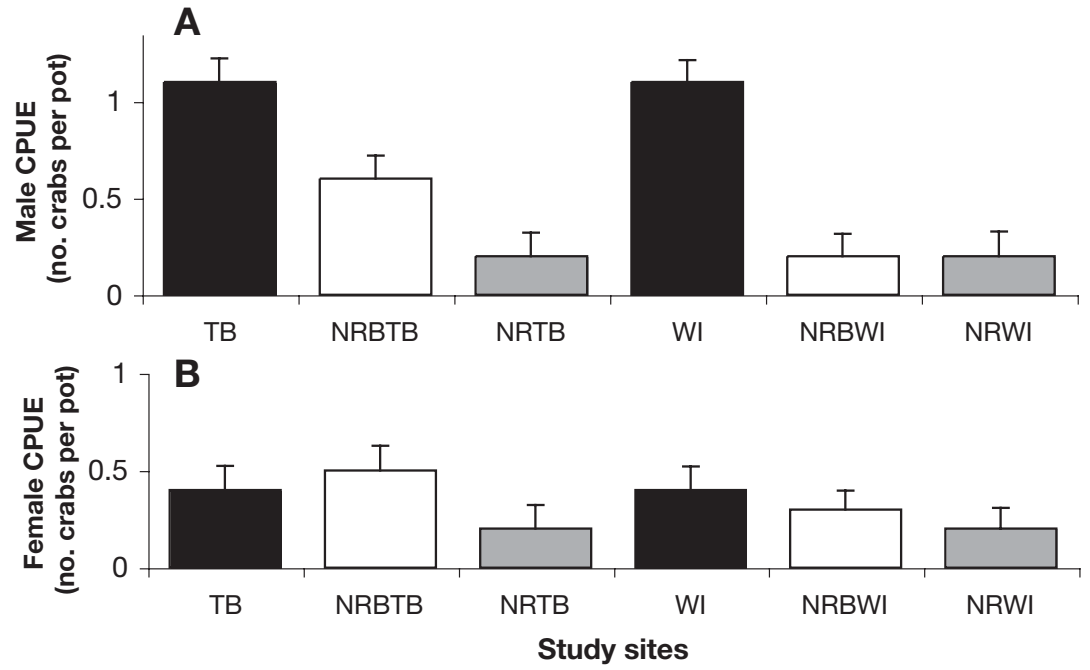

Fig. 3. Scylla serrata. Catch rates (no. of crabs per pot) ( $\pm 1 \mathrm{SE}$ ) of mud crabs between the 2 reserves (TB: Tripcony Bight; WI: Willes Island) and corresponding non-reserve sites (NRB: boundary non-reserve; NR: far non-reserve) (seasons pooled) for (A) males and (B) females
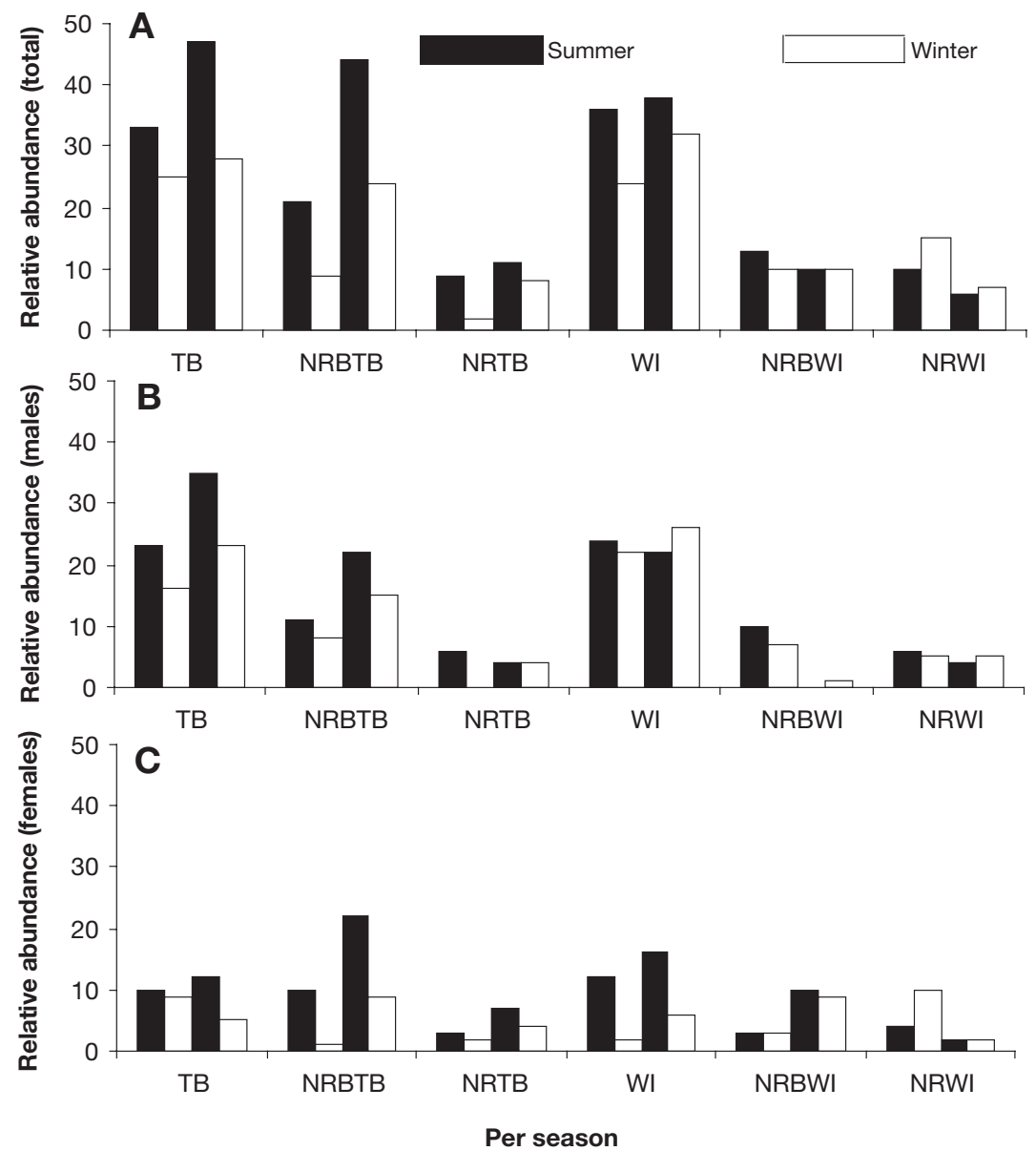

Fig. 4. Scylla serrata. Relative abundance (n) of mud crabs between the seasons (summer and winter) over 2 yr (2002-2003) between the 2 reserves (TB: Tripcony Bight; WI: Willes Island) and corresponding non-reserve sites (NRB: boundary nonreserve; NR: far non-reserve) for (A) total crabs, (B) males and (C) females. Closed bars represent summer and open bars denote winter for 2002 and 2003, respectively non-reserve site $\left(\mathrm{NRB}_{\mathrm{TB}}\right)$ which peaked in summer 2003 (Table 1, Fig. 4B). Catch rates of male $S$. serrata appeared to be slightly higher in the summer months compared to winter months, particularly in the reserve sites (Fig. 4B). The results of the model fit for catch rates of female $S$. serrata revealed no significant interactions; significant results were only obtained for factors status and season (Table 2). Catch rates for female crabs were similar between the reserve and non-reserve sites (Fig. 3B). In most cases, catch rates of female crabs were slightly higher in the summer months than in the winter months for all study sites, with a peak in the Tripcony Bight non-reserve site (NRB ${ }_{\mathrm{TB}}$ ) in summer 2003 (Fig. 4C).

\section{Size and sex}

The Kruskal-Wallis 1-way ANOVA for mean size of all Scylla serrata (males and females) revealed significant differences in the mean size of crabs between the reserve and non-reserve sites (status, p < 0.000) (Table 3). Multiple comparisons revealed that the mean size of $S$. serrata was also significantly different between the non-reserve sites (Tables 1 \& 3). The mean size of crabs did not change greatly between the seasons, whereas the mean size of crabs caught in non-reserve sites was more variable depending on the season. The size distributions of $S$. serrata were not found to be significantly different between the 2 reserves or between the Tripcony Bight reserve and the far nonreserve site $\left(\mathrm{NR}_{\mathrm{TB}}\right)$; however, all other comparisons between the reserves and non-reserve sites (and between nonreserve sites) were found to be significantly different $(\mathrm{p}<0.0001)$.

The Kruskal-Wallis 1-way ANOVA for the mean size of male Scylla serrata revealed that there were significant differences between the reserve and non-reserve sites (status, $\mathrm{p}<0.0001$ ) (Table 3). Multiple comparisons revealed there was no significant difference in the mean size of male crabs between the non-reserve sites (Tables 1 $\& 3)$. Of the male crabs caught in each 
Table 3. Scylla serrata. Kruskal-Wallis 1-way ANOVA of mean size (per pot) of total mud crabs, and male and female crabs caught between the marine reserves (R: reserves: Tripcony Bight and Willes Island) and 4 non-reserve sites (NRB: boundary nonreserve; NR: far non-reserve) with multiple comparisons of mean ranks for all groups within the factor Status (reserve, non-reserve)

\begin{tabular}{|c|c|c|c|c|c|c|c|c|c|c|c|c|}
\hline \multirow{3}{*}{$\begin{array}{l}\text { Factor } \\
\text { Status }\end{array}$} & \multirow{3}{*}{$\frac{\mathrm{df}}{}$} & \multirow{3}{*}{$\frac{\chi^{2}}{74.4}$} & \multirow{3}{*}{$\frac{p}{0.000}$} & \multirow{2}{*}{\multicolumn{2}{|c|}{$\begin{array}{l}\text { Total } \\
\text { Comparisons }\end{array}$}} & \multirow{3}{*}{$\begin{array}{c}\chi^{2} \\
87.5\end{array}$} & \multirow{3}{*}{$\begin{array}{c}p \\
0.000\end{array}$} & \multirow{2}{*}{\multicolumn{2}{|c|}{$\begin{array}{l}\text { Male } \\
\text { Comparisons }\end{array}$}} & \multirow{3}{*}{$\begin{array}{c}\chi^{2} \\
10.24\end{array}$} & \multirow{3}{*}{$\begin{array}{c}-\mathrm{p} \\
0.006\end{array}$} & \multirow{2}{*}{$\begin{array}{l}\text { male } \\
\text { Comparisons }\end{array}$} \\
\hline & & & & & & & & & & & & \\
\hline & & & & R vs. NRB & 0.000 & & & R vs. NRB & 0.000 & & & R vs. NRB \\
\hline & & & & R vs. NR & 0.000 & & & R vs. NR & 0.000 & & & R vs. NR $\quad 0.1$ \\
\hline & & & & NRB vs. NR & 0.01 & & & NRB vs. NR & 0.2 & & & NRB vs. NR 0.1 \\
\hline
\end{tabular}

of the study sites, over $70 \%$ of the crabs within the marine reserves were equal to or greater than legalsize $(15 \mathrm{~cm} \mathrm{CW})$ compared to fewer than $50 \%$ within the non-reserve sites (Table 1). The size distributions of male $S$. serrata were found to be significantly different between the reserve and all of the non-reserve sites $(\mathrm{p}<0.0001)$, with no significant difference found between the boundary non-reserve sites $\left(\mathrm{NRB}_{\mathrm{TB}}\right.$ and $\mathrm{NRB}_{\mathrm{WI}}$ ) and the Tripcony Bight non-reserve sites $\left(\mathrm{NRB}_{\mathrm{TB}}\right.$ and $\mathrm{NR}_{\mathrm{TB}}$ ) (Figs. 5A \& 6A).

Although the Kruskal-Wallis 1-way ANOVA for female Scylla serrata revealed a significant difference between the reserve and non-reserve sites (status, $\mathrm{p}<0.006$ ), no significant difference was detected by the multiple comparisons between the sites (Table 3). The mean size of female $S$. serrata did not differ greatly between the study sites (Table 1). Female size distribution was found to be significantly different between the reserve and the non-reserve sites ( $p<0.0001)$, with only 1 nonsignificant result detected between the Tripcony Bight non-reserve sites ( $\mathrm{NRB}_{\mathrm{TB}}$ and $\mathrm{NR}_{\mathrm{TB}}$ ) (Figs. 5B \& 6B).

\section{Sex ratio}

The results of the chi-square analysis revealed significant differences in the sex ratios of Scylla serrata between both marine reserves and their corresponding
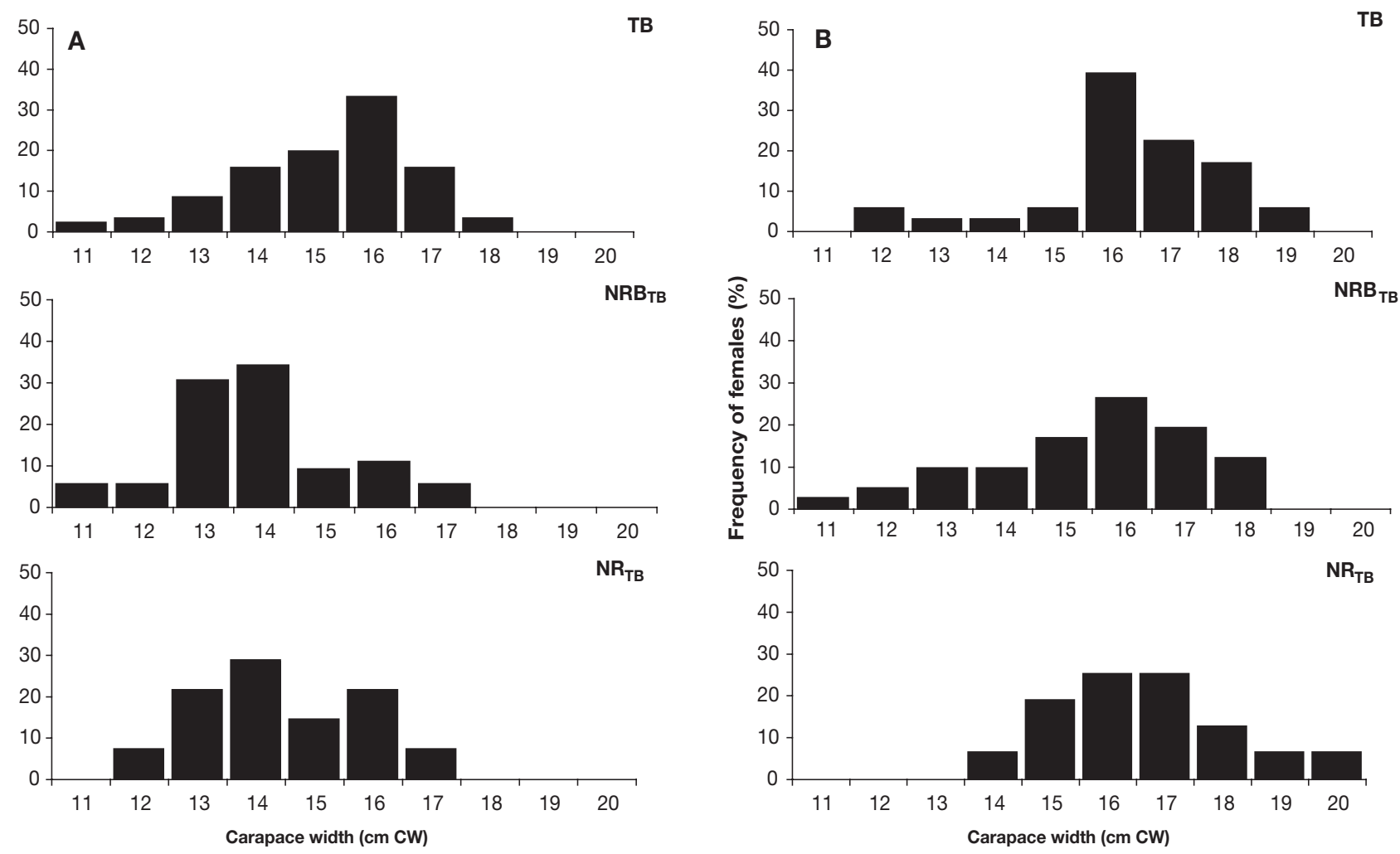

Fig. 5. Scylla serrata. Length-frequency (\%) data of mud crabs between Tripcony Bight reserve (TB) and the northern nonreserve sites $\left(\mathrm{NRB}_{\mathrm{TB}}, \mathrm{NR}_{\mathrm{TB}}\right.$ ) (pooled seasons) for $(\mathrm{A})$ males and (B) females. Male crabs $\geq 15 \mathrm{~cm} C W$ are of legal size and female crabs $\geq 12 \mathrm{~cm}$ CW are of mature size in Moreton Bay 

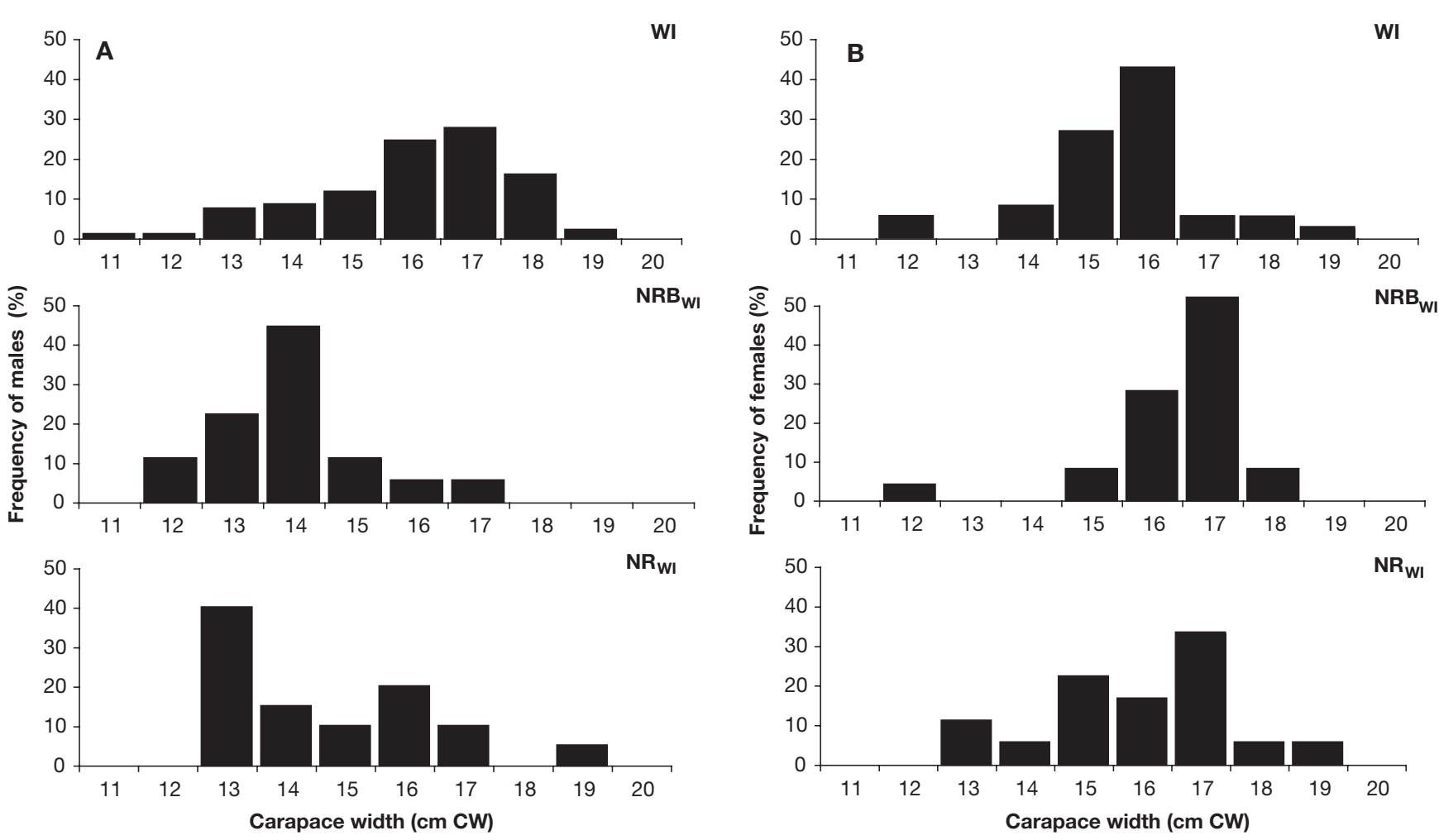

Fig. 6. Scylla serrata. Length-frequency (\%) data of mud crabs between Willes Island reserve (WI) and the southern non-reserve sites ( $\mathrm{NRB}_{\mathrm{WI}}, \mathrm{NR}_{\mathrm{WI}}$ ) (pooled seasons) for $(\mathrm{A})$ males and (B) females. Male crabs $\geq 15 \mathrm{~cm}$ CW are of legal size and female crabs $\geq 12 \mathrm{~cm} \mathrm{CW}$ are of mature size in Moreton Bay

non-reserve sites. In the Tripcony Bight reserve, 69 mature male $S$. serrata were caught compared to 36 mature female crabs, resulting in a sex ratio of $2: 1$ $\left(\chi^{2}=10.37, p<0.001\right)$. In the boundary non-reserve site $\left(\mathrm{NRB}_{\mathrm{TB}}\right), 14$ mature male crabs were caught compared to 41 mature female crabs resulting in a sex ratio of $0.34: 1\left(\chi^{2}=13.25, p<0.001\right)$, with a similar sex ratio of $0.38: 1\left(\chi^{2}=4.54, \mathrm{p}<0.03\right)$ observed in the far non-reserve site $\left(\mathrm{NR}_{\mathrm{TB}}\right)$, with 6 mature males caught compared to 16 mature female crabs. Within the Willes Island reserve, a total of 77 mature male $S$. serrata were caught compared to 36 mature females, resulting in a sex ratio of 2:1 (males to females) $\left(\chi^{2}=14.87, p<0.001\right)$. In the boundary non-reserve site $\left(\mathrm{NRB}_{\mathrm{WI}}\right), 4$ mature male crabs were caught compared to 25 mature females, resulting in a sex ratio of $0.16: 1\left(\chi^{2}=15.2, \mathrm{p}<\right.$ $0.001)$ and in the far non-reserve site $\left(\mathrm{NR}_{\mathrm{WI}}\right), 9$ mature male crabs were caught compared to 18 mature female crabs, resulting in a sex ratio of $0.5: 1\left(\chi^{2}=3.0, p<0.08\right)$.

\section{Crab movement}

A total of 203 Scylla serrata were tagged within the Tripcony Bight reserve; 42 crabs were tagged within the boundary non-reserve site $\left(\mathrm{NRB}_{\mathrm{TB}}\right)$ and 11 within the far non-reserve site $\left(\mathrm{NR}_{\mathrm{TB}}\right)$. Of those $S$. serrata tagged within the Tripcony Bight reserve, 19 crabs were recaptured, a $9 \%$ recapture rate. Over $50 \%$ of $S$. serrata recaptured inside the Tripcony Bight reserve were recorded by the authors (S.P.) $(n=10)$. Most of these crabs were recorded within 1 to $4 \mathrm{~d}$ of being tagged. Movement within the Tripcony Bight reserve was estimated to be $50 \mathrm{~m}$, which was the average distance between pots. Nine crabs tagged inside the reserve (all male) were recaptured outside the reserve by recreational anglers, resulting in a $4 \%$ recapture rate of crabs moving outside the reserve. Crabs were at liberty for $80 \mathrm{~d}$ on average (ranging from 8 to $223 \mathrm{~d}$ ). The distance traveled from the reserve boundary was approximately $2 \mathrm{~km}$, predominantly in an easterly direction with no dominant north or south direction recorded. One crab was recaptured from the boundary non-reserve site $\left(\mathrm{NRB}_{\mathrm{TB}}\right)$ and although the crab was at liberty for $62 \mathrm{~d}$, no movement outside this site was recorded. There was also a difference in the mean size of crabs recaptured outside the Tripcony Bight reserve compared to crabs caught in the corresponding nonreserve sites. The mean size of male crabs tagged inside the Tripcony Bight reserve and recaptured outside the reserve was $17 \%$ larger $(16.6 \mathrm{~cm} \mathrm{CW})$ than crabs caught in both non-reserve sites (14.2 cm CW). 
Within the Willes Island reserve, a total of 135 Scylla serrata were tagged; 9 crabs were tagged in the boundary non-reserve site $\left(\mathrm{NRB}_{\mathrm{WI}}\right)$ and 4 in the far non-reserve site $\left(\mathrm{NR}_{\mathrm{WI}}\right)$. The majority of crabs tagged in the reserve were recaptured inside the reserve boundary, resulting in a $13 \%$ recapture rate ( $\mathrm{n}=17$ ). Most of the crabs recaptured (88\%) inside the reserve were recorded within 2 to $5 \mathrm{~d}$ of being tagged (by S.P.). However, 2 S. serrata were recaptured 163 and $164 \mathrm{~d}$ after the initial tagging. The distance moved within the reserve was approximately $50 \mathrm{~m}$, which was the average distance between pots. Only $1 \mathrm{~S}$. serrata (large male, $17 \mathrm{~cm} \mathrm{CW}$ ) was recaptured outside the Willes Island reserve (a recapture rate of $<1 \%$ ); this was a long-term recapture with the crab at liberty for $300 \mathrm{~d}$. The crab was recaptured by a commercial crab fisher, approximately $25 \mathrm{~m}$ outside the reserve boundary.

\section{DISCUSSION}

Overall, our results indicate that when a species is imposed with sex-limits in a fishery the implementation of a marine reserve has the potential to reverse the effects of fishing and benefit the exploited species as well as the 'dominant' sex. Catch rates of adult Scylla serrata were higher in both marine reserves compared to all corresponding non-reserve sites. The CPUE of $S$. serrata also differed between seasons, with higher catches recorded in summer compared to winter months. This seasonal pattern was particularly strong in catches of crabs from the marine reserves, whereas high fishing pressure in the non-reserve sites probably reduced seasonal changes in catches. Previous studies of $S$. serrata in Moreton Bay have found higher catches of crabs in summer compared to winter (Williams \& Hill 1982). Our results are consistent with similar studies in which increases in catch rates (CPUE) of invertebrates have been detected in reserves worldwide (gastropod and sea urchin, Castilla 1996; gastropod, sea urchin and limpet, Castilla \& Fernandez 1998; abalone and lobster, Edgar \& Barrett 1999; lobster, Kelly et al. 2000, Davidson et al. 2002). Interestingly, the catch rates of S. serrata were almost identical between both marine reserves despite the Tripcony Bight reserve being 3 times larger in size than the Willes Island reserve. This result is consistent with numerous studies showing the benefits to exploited species despite small reserve size (see extensive review by Halpern 2003).

Using data from commercial catches of Scylla serrata in Moreton Bay, we were also able to compare catch rates between fished and unfished areas on a larger scale. Fisheries data (CHRIS 2003) available on the commercial harvest (i.e. biomass) of $S$. serrata in
Moreton Bay showed approximate catches of $300 \mathrm{~g}$ of crab per pot. This is based on commercial catch data (113.3 $\mathrm{t}$ in 2003), number of days fished (7743 d in 2003) and a maximum number of 50 crab pots per license (Queensland Fisheries Legislation, Williams 2002). Using our unpublished data (S.P.) of length/ weight measurements of $S$. serrata in Moreton Bay, the biomass of crabs caught in the marine reserves was approximately $900 \mathrm{~g}$ per pot, suggesting that the reserves in Moreton Bay have 3 times the biomass (estimated by catch rates) of $S$. serrata relative to the commercial fishery.

Sex-related differences in the catch rates of male and female Scylla serrata were obvious between the marine reserves and non-reserve sites. Male $S$. serrata dominated catches in both marine reserves, with 5 times more male crabs caught in the reserves compared to the non-reserve sites. The only exception was catches of male crabs in the Tripcony Bight boundary non-reserve site $\left(\mathrm{NRB}_{\mathrm{TB}}\right)$ in summer 2003, which were unexpectedly high (as were female numbers at this site during this season), perhaps due to a single heavy rainfall event. Heavy and prolonged rainfall has the potential to change water temperature and salinity, which in turn can influence catch rates of $S$. serrata (Williams \& Hill 1982). Although heavy rainfall occurred in all study sites, it only appeared to influence crab catches in the boundary non-reserve site $\left(\mathrm{NRB}_{\mathrm{TB}}\right)$, which is most likely due to a small creek located near this site which commonly floods after heavy rainfall (i.e. increasing crab catches). As marine reserves are commonly chosen on the basis of their 'uniqueness', the exact compatibility between reserve and nonreserve sites is almost impossible and we acknowledge this in our study. In terms of seasonal catch rates of male $S$. serrata, the highest catches in the reserves were in summer. In contrast, more variable catches of male crabs were recorded between the seasons in the non-reserve sites, perhaps due to consistent fishing pressure throughout the year. We expected an increase in catch rates of male $S$. serrata in the reserves because they are protected in the reserves and not outside.

In comparison, catch rates of female Scylla serrata did not reveal such strong patterns between the reserve and non-reserve sites. Catch rates of female crabs did not differ between the reserves and boundary non-reserve sites; however, there were twice as many female crabs caught in the reserves compared to the far non-reserve sites. Catch rates of female crabs between reserve and non-reserve sites were not expected to be very different because female $S$. serrata are totally protected (inside and outside the marine reserves). Interestingly, the catch rates of female $S$. serrata were almost always higher in the reserve 
compared to the non-reserve sites. Again, the only exception were catch rates of female crabs in the Tripcony Bight boundary non-reserve site $\left(\mathrm{NRB}_{\mathrm{TB}}\right)$, which as mentioned previously could be the result of a oneoff prolonged rainfall event. The higher catch rates of female $S$. serrata in both marine reserves could be due to several reasons. These include increased habitat quality and ecosystem function offered by total protection in reserves (Ward et al. 2001), non-compliance to fishery regulations outside the reserves (particularly in far non-reserve sites) or the possibility that female crabs may be attracted to areas with an abundance of large male crabs. Seasonal changes in water temperature in Moreton Bay were also reflected in catch rates of female crabs, with higher catch rates in summer compared to winter at all study sites.

The mean size of Scylla serrata was also significantly higher in both marine reserves compared to nonreserve sites. Within the reserves, the mean size of crabs did not change dramatically between the seasons whereas the mean size of crabs caught in nonreserve sites was more variable depending on the season. Again, sex-related differences were detected in the average size of $S$. serrata; male crabs were on average $10 \%$ larger in both marine reserves compared to the non-reserve sites, which was expected due to the protection offered by the reserves. Not only were male crabs larger in size, but within both marine reserves, legal-sized male $S$. serrata made up $>70 \%$ of the total male catch in both reserves, whereas within nonreserve sites, $<50 \%$ of male crabs were of legal size. The skewed size distribution of male crabs in both marine reserves in this study further reflects the impact the mud crab fishery has in Moreton Bay. Increases in the average size of crustaceans have also been detected in marine reserves for spiny lobster Jasus edwardsii in New Zealand (Kelly et al. 2000, Davidson et al. 2002) and American lobster Homarus americanus in Newfoundland (Rowe 2002). In contrast, the average size of female $S$. serrata in our study did not differ greatly between the reserve and non-reserve sites which is probably due to the total protection offered to female crabs at all study sites.

It is clear from our results that the sex-biased fishery in Moreton Bay impacts heavily on the catch rates and mean size of Scylla serrata. Within both marine reserves, almost identical proportions of mature male and female crabs were caught resulting in a sex ratio of 2:1 (male:female). The opposite sex ratio was displayed in the non-reserve sites, skewed towards more females. The only records documenting sex ratios of $S$. serrata in the Moreton Bay fishery are population estimates carried out by fisheries agencies more than $10 \mathrm{yr}$ ago which revealed that although there were seasonal variation in sex ratios, adult female $S$. serrata often outnumbered adult male crabs (Coates 1993), no doubt a result of the male-only fishery. Consequently, due to the nature of the mud crabs fishery in Moreton Bay, a skew in sex ratios between reserve and nonreserve sites was predicted. However, it was not expected that the sex ratio in both marine reserves would be so skewed towards males. If both sexes were totally protected by the marine reserves, it was anticipated that the sex ratio would be almost equal.

Ward et al. (2001) argues that only examining sex ratios can be misleading as the sex ratio can disguise the fact that structural change to the population is being induced through fishing; therefore, it is not clear how sex ratios in such adapted populations would respond in a marine reserve. The only study we are aware of noting the sex ratio of Scylla serrata in a 'protected' situation is the study of Hill (1975) who studied $S$. serrata in 2 South African estuaries. One was open to the sea whilst the second estuary was closed by a sandbar providing 'protection'. Neither of the estuaries was impacted by fishing. Analysis of the sex ratios of $S$. serrata from the 'open' estuary showed that approximately $14 \%$ of crabs larger than $13 \mathrm{~cm} \mathrm{CW}$ were female. Hill suggested this low proportion of females was probably due to a migration of female crabs out of the estuary to spawn at sea. A similar migration could not occur from the 'closed' estuary and the proportion of females remained relatively constant at approximately $43 \%$ throughout the size range of 11 to $16.9 \mathrm{~cm}$ CW. As previously mentioned, if both sexes were totally protected by marine reserves, or in this case by physical closure, it was anticipated that the sex ratio would be almost equal. Sex ratios were almost equal in the 'protected' estuary in Hill's (1975) study; however, the sex ratios of fully protected $S$. serrata in our study were skewed towards males. The results of our study demonstrate that reserves have the potential to allow exploited species to recover from the effects of fishing and to return to their 'natural' state. In Moreton Bay, the 'natural' state revealed by the 2 marine reserves was a sex ratio of 2:1 (male:female).

Documenting the movement of economically important species is important to determine whether the existing marine reserves are effective in conserving stocks from harvest. There is good evidence from tagging studies that fisheries species have benefited from reserves through 'spillover' (density-dependence) of juveniles and adults to adjacent fishing grounds (e.g. Attwood \& Bennett 1994, Johnson et al. 1999, Roberts et al. 2001, Griffiths \& Wilke 2002). In this study, the term 'spillover' relates to the cross-boundary movement of Scylla serrata, with no implications for densitydependence as defined by Kramer \& Chapman (1999). This is due to the crab recapture rates outside the reserves not being inversely proportional to the rela- 
tive abundance inside the reserves. Tagging studies on crustaceans within marine reserves are limited; however, recent studies in Japan (on crabs), New Zealand and Newfoundland (on lobsters) have revealed movements of invertebrates between reserves and fished sites (e.g. Yamasaki \& Kuwahara 1990, Kelly 2001, Rowe 2002). Due to the sedentary nature of $S$. serrata (with the exception of female mud crabs during spawning, Hill 1994), movement outside of reserves was expected to be minimal. This was evident in our study, with the majority of $S$. serrata recaptured in the same areas, and with only a $4 \%$ recapture rate outside the Tripcony Bight reserve and less then a $1 \%$ recapture rate outside the Willes Island reserve. Hill (1975) showed that $S$. serrata are capable of considerable movement but seem to remain in the same area for long periods. Hyland et al. (1984) also found that most $S$. serrata tagged in Moreton Bay were recaptured in the same area where they had been released. Even though only small numbers of crabs were tagged (and therefore recaptured) within this study, recapture information is still noteworthy as no similar tagging studies have been carried out on $S$. serrata within marine reserves in Australia.

It appears that invertebrate species with small home ranges, such as Scylla serrata, have limited potential for spillover (cross-boundary movements) from reserves. Generally, the extent to which spillover occurs, and its timing, is related to the design and size of the reserve, the biological characteristics of the species involved, and the management system in place to enforce marine reserves (Ward et al. 2001). Although the tagging data in this study demonstrated the limited movement of $S$. serrata within 2 small marine reserves, it also revealed this species' ability to move outside reserve boundaries into adjacent fishing areas. Interestingly, all crabs tagged within the reserves which were later caught in fished sites were at least $10 \%$ larger than the MSL for this species. Furthermore, the results of this study agree with the popular notion that marine reserve effectiveness largely depends on the mobility of the target species, with the more sedentary animals, such as crustaceans, most likely to be protected (and show significant differences) in reserves of a small size (Edgar \& Barrett 1999, Griffiths \& Wilke 2002).

It is also interesting to note that the large differences observed in crabs between the reserve and nonreserve sites could also be related to the short life cycle of Scylla serrata. The 2 marine reserves surveyed in this study are a fairly recent addition to the Marine Park (established in 1997), yet $S$. serrata are shortlived. We may not have found such large differences between reserve and non-reserve sites with a longlived species. As well as being short-lived, $S$. serrata are also highly fecund (2 to 8 million eggs) and are capable of multiple-spawning (Heasman 1980, Heasman et al. 1985). Increases in the abundance (density) and size of reproductive individuals within marine reserves has important consequences in maximizing the reproductive capacity of natural populations (Manriquez \& Castilla 2001) as well as having the potential to export larvae to surrounding areas, known as 'seeding grounds' (Fernandez \& Castilla 1997). Although these 2 concepts are beyond the scope of this paper, we can make predictions based on the biology and patterns displayed by adult $S$. serrata to marine reserve protection in Moreton Bay. We predict that the reproductive output from the reserves is likely to be higher than outside fished areas due to higher numbers of large males being more likely to successfully fertilize female mud crabs (see Davidson et al. 2002, lobsters). In terms of 'seeding' adjacent fishing grounds (i.e. nonreserve sites), it is believed that adult female $S$. serrata migrate offshore to spawn (Hill 1994), so the potential for female mud crabs to 'seed' non-reserve sites in our study would be low. Further research into the fecundity and larval biology of $S$. serrata and coastal oceanography within Moreton Bay would be necessary to support this prediction. Again, this highlights the importance of knowing the biology of the species targeted for protection to adequately design and manage effective marine reserves.

\section{CONCLUSION}

Empirical testing of marine reserves still remains one of the most critical aspects in improving the design and management of future marine reserves. The results of this study add to the growing body of empirical evidence that small marine reserves $(<6$ $\mathrm{km}^{2}$ ) can provide conservation and fisheries benefits for exploited species (particularly for less mobile invertebrate species). Our results strengthen the case for the implementation of more marine reserves in the Moreton Bay Marine Park, especially for the future protection of Scylla serrata populations. In particular, networks of small marine reserves (between 2 and 10 $\mathrm{km}^{2}$ in area) are recommended to provide both fisheries and conservation benefits to $S$. serrata in subtropical Australia.

Acknowledgements. We thank the CRC for Coastal Zone, Estuary and Waterway Management, the Department of Premier and Cabinet, and the Centre for Marine Studies of the University of Queensland for providing funding and financial assistance to S.P. Many thanks to D. Round and M. Round for field assistance; J. C. Ortiz for statistical assistance; and to B. Sawynok (Suntag) for storing tagging data. Thanks to B. Hill and 3 anonymous reviewers for constructive comments on the manuscript. 


\section{LITERATURE CITED}

Attwood CA, Bennett BA (1994) Variation in dispersal of galjoen (Corancinus capensis) (Teleostei: Coracinidae) from a marine reserve. Can J Fish Aquat Sci 51:1247-1257

Brown IW (1993) Mangrove crabs. In: Wright A, Hill L (eds) Nearshore marine resources of the South Pacific. Institute of Pacific Studies (Suva), Forum Fisheries Agency (Honiara), International Centre for Ocean Development (Canada), p 609-642

Buxton CD (1992) The application of yield-per-recruit models to two South African sparid reef species, with special consideration to sex change. Fish Res 15:1-16

Buxton CD (1993) Life-history changes in exploited reef fishes on the east coast of South Africa. Environ Biol Fish 36: $47-63$

Castilla J (1996) Chilean resources of benthic invertebrates: fishery, collapses, stock rebuilding and the role of coastal management areas and national parks. In: Hancock DA, Smith DC, Grant A, Beumer JP (eds) Developing and sustaining world fisheries resources: the state of science and management. CSIRO, Collingwood, p 130-135

Castilla JC, Fernandez M (1998) Small-scale benthic fisheries in Chile: on co-management and sustainable use of benthic invertebrates. Ecol Appl 8(1):S124-S132

Chapman MR, Kramer DL (1999) Gradients in coral reef fish density and size across the Barbados marine reserve boundary: effects of reserve protection and habitat characteristics. Mar Ecol Prog Ser 181:81-96

Chiappone M, Sluka R, Sullivan Sealey K (2000) Groupers (Pisces: Serranidae) in fished and protected areas of the Florida Keys, Bahamas and northern Caribbean. Mar Ecol Prog Ser 198:261-272

CHRIS (2003) Coastal Habitat Resources Information System, Department of Primary Industries Queensland Fisheries Service, Brisbane. http://chrisweb.dpi.qld.gov.au

Coates M (1993) Should female mud crabs be protected? Report to Queensland Commercial Fishermen's Organization, Rockhampton

Davidson RJ, Villouta E, Cole RG, Barrier RGF (2002) Effects of marine reserve protection on spiny lobster (Jasus edwardsii) abundance and size at Tonga Island marine reserve, New Zealand. Aquat Conserv 12:213-227

Dugan JE, Davis GE (1993) Applications of marine refugia to coastal fisheries management. Can J Fish Aquat Sci 50: 2029-2042

Edgar GJ, Barrett NS (1997) Short term monitoring of biotic change in Tasmanian marine reserves. J Exp Mar Biol Ecol 213:261-279

Edgar GJ, Barrett NS (1999) Effects of the declaration of marine reserves on Tasmanian reef fishes, invertebrates and plants. J Exp Mar Biol Ecol 242:107-144

Environmental Protection Agency (1999) Moreton Bay marine ark zoning plan summary. Queensland Parks and Wildlife Service, Brisbane

Fernandez M, Castilla JC (1997) The Chilean artisanal stone crab (Homalaspis plana) fishery: catch trends in open access zones and the effect of management areas in central Chile. J Shellfish Res 16(2):371-377

Fielder DF, Heasman MP (1978) The mud crab. A Queensland museum booklet. Queensland Museum, Brisbane

Garcia-Charton JA, Williams ID, Perez-Ruzafa A, Milazzo M and 5 others (2000) Evaluating the ecological effects of Mediterranean marine protected areas: habitat, scale and the natural variability of ecosystems. Environ Conserv 27(2):159-178

Gell FR, Roberts CM (2003) Benefits beyond boundaries: the fishery effects of marine reserves. Trends Ecol Evol 18(9): 448-455

Griffiths MH, Wilke CG (2002) Long-term movement patterns of five temperate-reef fishes (Pisces: Sparidae): implications for marine reserves. Mar Freshw Res 53:233-244

Halpern B (2003) The impact of marine reserves: do reserves work and does reserve size matter? Ecol Appl 13(1): S117-S137

Hawkins JP, Roberts, CM (2003) Effects of fishing on sexchanging Caribbean parrotfishes. Biol Conserv 115: 213-226

Heasman MP (1980) Aspects of the general biology and fishery of the mud crab Scylla serrata (Forskal) in Moreton Bay, Queensland. PhD thesis, University of Queensland, Brisbane

Heasman MP, Fielder DR, Shepherd RK (1985) Mating and spawning in the mud crab Scylla serrata (Forskål) (Decapoda: Portunidae), in Moreton Bay, Queensland. Aust J Mar Fresh Res 36:773-783

Hill BJ (1975) Abundance, breeding and growth of the crab Scylla serrata in two South African estuaries. Mar Biol 32: $119-126$

Hill BJ (1976) Natural food, foregut clearance-rate and activity of the crab Scylla serrata. Mar Biol 34:109-116

Hill BJ (1978) Activity, track and speed of movement of the crab Scylla serrata in an estuary. Mar Biol 47:135-141

Hill BJ (1994) Offshore spawning by the portunid crab Scylla serrata (Crustacea: Decapoda). Mar Biol 120:379-384

Hill BJ, Williams MJ, Dutton P (1982) Distribution of juvenile, subadult and adult Scylla serrata (Crustacea: Portunidae) on tidal flats in Australia. Mar Biol 69:117-120

Hyland SJ, Hill BJ, Lee CP (1984) Movement within and between different habitats by the portunid crab Scylla serrata. Mar Biol 80:57-61

Johnson DR, Funicelli NA, Bohnsack JA (1999) Effectiveness of an existing estuarine no-take fish sanctuary within the Kennedy Space Center, Florida. N Am J Fish Man 19: 436-453

Kailola PJ, Williams MJ, Stewart PC, Reichelt RE, McNee A, Grieve C (1993) Australian fisheries resources. Bureau of Resource Sciences, Department of Primary Industries and Energy and the Fisheries Research and Development Corporation, Canberra

Kelly S (2001) Temporal variation in the movement of the spiny lobster Jasus edwardsii. Mar Freshw Res 52: 323-331

Kelly S, Scott D, MacDiarmid AB, Babcock RC (2000) Spiny lobster, Jasus edwardsii, recovery in New Zealand marine reserves. Biol Conserv 92:359-369

Kelly S, Scott D, MacDiarmid AB (2002) The value of the spillover fishery for spiny lobsters around a marine reserve in Northern New Zealand. Coast Manage 30:153-166

Kramer DL, Chapman MR (1999) Implications of fish home range size and relocation for marine reserve function. Environ Biol Fish 55:65-79

Lubchenco J, Palumbi SR, Gaines SD, Andelman S (2003) Plugging a hole in the ocean: the emerging science of marine reserves. Ecol Appl 13(1):S3-S7

MacDiarmid AB, Breen PA (1992) Spiny lobster population change in a marine reserve. In: Battershill CN, Schiel DR, Jones GP, Creese RG, MacDiarmid AB (eds) Proceedings of the second international temperate reef symposium. NIWA Marine, Wellington, p 47-56

Manriquez PH, Castilla JC (2001) Significance of marine protected areas in central Chile as seeding grounds for the gastropod Concholepas concholepas. Mar Ecol Prog Ser 215:201-211 
McClanahan TR, Muthiga A, Kamukuru H, Machano H, Kiambo RW (1999) The effects of marine parks and fishing on coral reefs of northern Tanzania. Biol Conserv 89:161-182

Queensland Parliamentary Counsel (1997) Marine Parks (Moreton Bay) Zoning Plan 1997 in conjunction with Marine Parks Act 1982 and Marine Parks Amendment Regulation (No. 2) 1997

Roberts CM, Hawkins JP (2000) Fully protected marine reserves: a guide. WWF Endangered Seas Campaign, Washington DC, and University of York

Roberts CM, Polunin NVC (1991) Are marine reserves effective in management of reef fisheries? Rev Fish Biol Fish 1: 65-91

Roberts CM, Bohnsack JA, Gell F, Hawkins JP, Goodridge R (2001) Effects of marine reserves on adjacent fisheries. Science 294:1920-1923

Robertson WD, Kruger A (1994) Size at maturity, mating and spawning in the portunid crab Scylla serrata (Forskal) in Natal, South Africa. Estuar Coast Shelf Sci 39:185-200

Rowe S (2002) Population parameters of American lobster inside and outside no-take reserves in Bonavista Bay, Newfoundland. Fish Res 56:167-175

Rowley RJ (1994) Marine reserves in fisheries management. Aquat Conserv 4:233-254

SAS (2003) SAS Software version 9.1. SAS Institute, Cary, NC

Underwood AJ (1994) On beyond BACI: sampling designs that might reliably detect environmental disturbances. Ecol Appl 4:3-15

Editorial responsibility: Otto Kinne (Editor-in-Chief), Oldendorf/Luhe, Germany
Ward TJ, Heinemann D, Evans N (2001) The role of marine reserves as fisheries management tools: a review of concepts, evidence and international experience. Bureau of Rural Sciences, Canberra

Williams LE (ed) (2002) Queensland's fisheries resources: current condition and recent rends 1988-2000. QI02012. Department of Primary Industries Queensland, Brisbane

Williams MJ, Hill BJ (1982) Factors influencing pot catches and population estimates of the portunid crab Scylla serrata. Mar Biol 71:187-192

Williamson DH, Russ GR, Ayling AM (2004) No-take marine reserves increase abundance and biomass of reef fish on inshore fringing reefs of the Great Barrier Reef. Environ Conserv 31(2):149-159

Willis TJ, Millar RB, Babcock RC (2003) Protection of exploited fish in temperate regions: high density and biomass of snapper Pagrus auratus (Sparidae) in northern New Zealand marine reserves. J Appl Ecol 40:214-227

Yamasaki A, Kuwahara A (1990) Preserved area to effect recovery of over-fished Zuwai crab stocks off Kyoto Prefecture. In: Proceedings of the international symposium on king and tanner crabs. Alaska Sea Grant Program Report 90-04, Fairbanks, p 575-585

Zar JH (1984) Biostatistical analysis, 2nd edn. Prentice Hall, NJ

Zeller B (1998) Queensland's fisheries habitats: current condition and recent trends. QI98025. Department of Primary Industries Queensland, Brisbane

Submitted: May 25, 2004; Accepted: March 8, 2005

Proofs received from author(s): May 27, 2005 